\title{
A retrospective review of the factors that negatively influenced the eradication of polio in South-South, Nigeria
}

\author{
Peters Grace $E^{1 *}$, Assi Victor ${ }^{2}$, Oko Nnabuike $E^{3}$ and Peters \\ Etete $\mathrm{J}^{4}$
}

${ }^{1}$ Department of Nursing Sciences, University of Uyo, Uyo, Nigeria

${ }^{2}$ Department of Sociology, Ritman University, Ikot, Ekpene, Nigeria

${ }^{3}$ Department of Administration, University of Uyo, Teaching Hospital, Uyo, Nigeria

${ }^{4}$ Department of Internal Medicine, University of Uyo. Uyo, Nigeria

\section{Abstract}

Background: The endemic nature of poliomyelitis in Nigeria was a source of concern to many given the global efforts aimed at eradicating the scourge. In this study, the factors that influenced the eradication of this malady in South-South Nigeria (Akwa Ibom and Cross River State) were investigated. Four null hypotheses, drawn on these factors (including culture belief, religious difference, language and the prevalence of ethnic conflict) guided the investigation.

The main thrust of this study was to examine how socio-cultural factors negatively influenced the eradication of polio in the study area.

Methods: Through stratified random and purposive sampling techniques, 600 adult men and women who had children were selected for the study. A structured questionnaire constructed by the researcher was used in data collection. Data analysis was carried out using one-way ANOVA and independent t-test statistical tools.

Results: The findings were that cultural belief and religious affiliation exerted significant influence on the people's effort towards polio eradication.

Conclusion: The study indicated that the low use of health services by the people was brought about by variation in these variables. Among other things, it was suggested that continuous awareness campaigns be carried out to educate the people on the need for immunization anchored in science and technology.

\section{Introduction}

The World Health Organization [1], defines health as "a state of complete physical, mental and social wellbeing and not merely the absence of disease or infirmity [2]. However, from the medical point of view, according to Etobo, [3], health is a condition in which all functions of the body and mind are normally active, meaning that a person of low physiological activity is said to be unhealthy. Therefore, a healthy individual is a person who is able to have a harmonious state functioning socially and psychologically. This is to say thus, that one's state of healthiness is measured in terms of his/her ability to have an intra-psychic balance and good interpersonal relationship.

\begin{abstract}
More Information
*Address for Correspondence: Peters Grace E, $\mathrm{PhD}$, Department of Nursing Sciences, University of Uyo, Uyo, Nigeria, Tel: +2348036846609; Email: etetepeters@yahoo.com; graceepeters@yahoo.com

Submitted: July 13, 2021

Approved: July 29, 2021

Published: July 30, 2021

How to cite this article: Peters Grace E, Victor A, Oko Nnabuike E, Peters Etete J. A retrospective review of the factors that negatively influenced the eradication of polio in South-South, Nigeria. J Community Med Health Solut. 2021; 2: 021-024.

DOI: 10.29328/journal.jcmhs. 1001011

Copyright: @ 2021 Peters Grace E, et al. This is an open access article distributed under the Creative Commons Attribution License, which permits unrestricted use, distribution, and reproduction in any medium, provided the original work is properly cited.
\end{abstract}

Keywords: Poliomyelitis; Immunization; Factors; Eradication

Check for updates

OPEN ACCESS 
The infection spread directly from person to person contact; contact with mucus or phlegm from the nose or mouth; or by contact with infected faeces. Human beings are the only carrier of polio virus which affects both males and female equally. Poliomyelitis is caused by polio virus and they include $\mathrm{P}_{1}, \mathrm{P}_{2}$ and $\mathrm{P}_{3}$. They are recognized by the body immune system based on how they relate to one another (serotype). About $90 \%-95 \%$ of the polio infection does not produce any symptom or damage but the infected person is capable of infecting others because of the presence of virus in the faeces. There are three types of polio ravaging mankind which include, spinal polio, bulbar polio and bulb spinal polio which are simply a combination of the other two [4].

Many children in underdeveloped and developed countries were susceptible to polio infection. Therefore, with the successful development of vaccines and the implementation of global vaccination campaign, the infection has been drastically reduced globally and completely eradicated in most countries including Nigeria [6]. In the past, many children have died, some paralyzed because of this childhood killer disease called polio thereby dashing the hopes of parents on their children. To prevent this, many parents sought for medicines or treatments in the hands of herbalists and oracle which involved sacrifices and a number of rituals to appease the gods believed to be responsible for the unfortunate malady.

However, in contemporary society, the campaign against polio was being spearheaded by the Global Polio Eradication Initiative, a network of parents including National Governments, the Rotary International, and the US Centre for Disease Control and Prevention, the Red Cross, as well as UNICEF, WHO and other volunteers and health workers. The campaign was to reach every child under the age of five.

Thus, despite the huge governments' budgetary allocations to the Ministry of Health in Nigeria for the eradication of polio through immunization, the nation could not achieve immediate success due to factors such as corruption, poor policy implementation, religion, ethnic conflict, culture/belief systems and poor communication among others [7]. The rapid spread of polio in Nigeria was an issue of great concern as there was no state in the country that had not been hit by the unfortunate malady caused by the virus. It was against this backdrop that this study sought to retrospectively review and evaluate the various factors that negatively influenced polio eradication in Cross River State and Akwa Ibom State of Nigeria.

\section{Cultural belief and polio eradication}

Culture is the way of life of a social group: the group's total man-made environment, including products of the group which are transmitted from one generation to another [8].

According to Ekong, [9], cultural belief is an important factor that hindered the eradication of polio in Nigeria. He argued that cultural belief, background of the people and health facilities available determine the behavior of the people towards service for polio eradication. This explained why most rural populace went to the modern hospitals as a last rather than first resort even when such hospitals were close to them.

Warraich, [10] observed that the Hausa name for polio is "Shan-inna". The understanding and meaning given to this disease differ between Western Science/biomedicine and Hausa culture. In biomedicine, the term polio is caused by a virus and is prevented through scientific method of immunization, while in Hausa culture, Shan-inna is an ailment of the spirit world. He argued that among the Hausa communities, it remains a strong belief that Shan-inna is a powerful female spirit that consumed the limbs of human beings. This made traditional healers to be greatly respected in the Hausa community as they are believed to have special powers that enabled them to interact with the spirit world. They are usually the first port of call when one has been affected by Shan-inna, particularity to those living in rural areas with the traditional healers as the only doctors' around.

Grange (2008) estimated that $80 \%$ - $85 \%$ of Nigerians and African as a whole rely on traditional healers for health education and health care.

Ademuwangun, [11] posited that cultural beliefs accounted for over 70\% of poor health of infants in the 1970's in Yoruba, Nigeria even when the infant immunization programme was available for the people to access.

Renne, [12], in an extensive study carried out in Zaria, argued thatcultural and religious belief of the peopleaccounted for over $60 \%$ low utilization of infant immunizations and added that there was need for proper education of the people if the fight against infant diseases like polio must be won.

\section{Religious belief and polio eradication in Nigeria}

In the early 2000s, Islamic religious leaders in Northern Nigeria advised their followers not to have their children vaccinated with the oral polio vaccine. The boycott caused the vaccination programme to be delayed thus causing cases of polio to rise not only in Nigeria but also in neighboring countries [13]. The followers were also wary of other vaccinations and Nigeria reported over 20,000 measles cases and nearly 600 deaths from measles from January through March 2005 [14].

Warraich, [10] contended that opposition by Muslim fundamentalists was a major factor in the failure of polio immunization programmes in Paskistan and Afghanistan.

In the USA, Leblanc, [15], observed that all but two state allowed parents of their children's otherwise mandatory vaccinations for religious reasons. The number of religious exemptions rose greatly in the late 1990s and early 2000s. 
For example, in Massachusetts, the rate of those seeking exemptions rose from $0.24 \%$ in 1996 to $0.60 \%$ in 2006 . He stressed that some parents were falsely claiming religious belief in order to get exemptions adding that the American Medical Association opposed such exemptions because they endanger health not only for the unvaccinated individual, but also for neighbors and the community at large.

\section{Methodology}

\section{Study design}

The research design for the study was survey research design.

\section{Study location}

The study area was South-South Nigeria (Cross River and Akwa Ibom State).

\section{Study population}

The population of the study group comprised all the residents of the two state understudy (Cross River and Akwa Ibom States) with a population of 3,920,208 and 2,888,966 respectively. The target population however were adult men and women with children, whose responsibility was to take such children to the health facilities for immunization.

\section{Sample size}

A sample size of six hundred (600) was adopted, 300 each from a state.

\section{Sampling techniques}

Stratified random sampling and purposive sampling were adopted. The two states were stratified based on the senatorial district in the state; six (6) Senatorial Districts were used for the study. In each of the stratum (State and senatorial District), 100 respondents were randomly selected as the sample for the study. The study adopted a five point Linkert scale questionnaire, to elicit information from respondents'.

Method of data analysis: A one -way ANOVA test was used in testing the questionnaire.

\section{Results}

The result from table 1 as shown above revealed that, 297 $(34.5 \%)$ of the total population were male, while $293(65.6 \%)$ were female. The age distribution of the respondents revealed that, $276(46 \%)$ of the total population were of the age $21-30$ years, $249(42.5 \%)$ of the population sampled were $31-40$ years, while $75(12.5 \%)$ of the total population were 41 years and above. The educational qualification of the respondents showed that $163(27.26 \%)$ of the total population primary education, $334(55.7 \%)$ of the population had secondary education and $103(17.2 \%)$ of the entire population sampled had tertiary education. This implied that the population is literate. The Table revealed that $408(68 \%)$ of the population were Christians, 129 (21.5\%) of the population were Muslim and $63(10.5 \%)$ of the total population belongs to other religious group in the state (Table 2).

In this hypothesis, the independent variable is the extent of cultural belief which was assigned three independent levels (strong, moderate and weak). The dependent variables on the other hand was the effort at polio eradication. The table showed the calculated F-value represents the observed difference among these groups of respondents in their polio eradication effort was 8.40 while $p$ - value $=.003$ at 0.05 significant level. Since the $p$ - value .003 is less than $(.003$ $<.0 .05$ ), hence the null hypothesis is rejected and it can be concluded, "cultural factors have significant effect and polio eradication in Nigeria." Thus this implies that cultural belief of the people has effect and a determining factor in polio eradication in Nigeria.

The result on Table 3 showed the value of the differences among the groups (Christian, Muslims and other religious) in their polio eradication efforts as detected in the analysis. The result revealed that the calculated $F$ - ratio of 7.38 while the $p$-value .003 is less that $(.001<.0 .05)$, hence. Because of this result, the null hypothesis was rejected while alternate was retrained. Thus it implies that Christians and Muslims differ significantly in their effort and polio eradication; a significant different thus exist between Muslims and other religion groups but there is no significant different between Christians and other religion groups in their effort at eradication polio.

\begin{tabular}{|c|c|c|c|c|}
\hline S/N & Personal Variable & Classification & Frequency & $\%$ \\
\hline \multirow[t]{2}{*}{1} & \multirow[t]{2}{*}{ Sex } & Male & 297 & 34.5 \\
\hline & & Female & 393 & 65.6 \\
\hline \multirow[t]{3}{*}{2} & Age & $21-30$ years & 276 & 46 \\
\hline & & $31-40$ years & 249 & 42.5 \\
\hline & & 41 years and above & 75 & 12.5 \\
\hline \multirow[t]{3}{*}{3} & Educational qualification & Primary Education & 163 & 27.16 \\
\hline & & Secondary Education & 334 & 55.67 \\
\hline & & Tertiary Education & 103 & 17.17 \\
\hline \multirow[t]{3}{*}{4} & Religion & Christian & 408 & 68 \\
\hline & & Muslim & 129 & 21.5 \\
\hline & & Others & 63 & 10.5 \\
\hline
\end{tabular}

Table 2: One -way analysis of Variance (ANOVA) of the influence of cultural belief on the effort towards polio eradication.

\begin{tabular}{|c|c|c|c|c|c|c|}
\hline S/N & Extent of Cultural Belief & \multicolumn{2}{c|}{ N } & \multicolumn{2}{c|}{ X } & SD \\
\hline 1 & Strong & \multicolumn{2}{|c|}{125} & 26.84 & 8.63 \\
\hline 2 & Moderate & \multicolumn{2}{|c|}{149} & 29.49 & 8.21 \\
\hline 3 & Weak & \multicolumn{2}{|c|}{326} & 32.68 & 7.82 \\
\hline Sources of variation & SS & df & MS & $\boldsymbol{f}$ - value & $\boldsymbol{p}$ - value & Remarks \\
\hline Between Groups & 104.36 & 2 & 52.18 & & & \\
\hline Within Groups & 3703.37 & 597 & 6.21 & $8.40^{*}$ & 0.003 & * Sig. \\
\hline Total & 3811.73 & 599 & & & & \\
\hline
\end{tabular}

Source: Research Fieldwork.

a. Dependent Variable: Polio Eradication.

b. Predictors (Constant): Cultural belief (strong, moderate and weak)

${ }^{*} p$. 003, level of significant $0.05, \mathrm{df}=2$ and 597 , critical $f=8.40$ 
Table 3: One-way analysis of variance (ANOVA) of the influence of religious difference on the effort towards polio eradication.

\begin{tabular}{|c|c|c|c|c|c|c|}
\hline \multicolumn{2}{|c|}{ Religious Group } & \multicolumn{2}{c|}{ N } & \multicolumn{2}{c|}{ X } & SD \\
\hline \multicolumn{2}{|c|}{ Christian } & \multicolumn{2}{c|}{408} & 33.34 & 6.67 \\
\hline \multicolumn{2}{|c|}{ Muslims } & \multicolumn{2}{c|}{129} & \multicolumn{2}{c|}{26.93} & 8.02 \\
\hline Others & \multicolumn{2}{|c|}{63} & \multicolumn{2}{c|}{32.86} & 6.14 \\
\hline Sources of Variation & SS & df & MS & $\boldsymbol{f}$ - value & $\boldsymbol{p}$ - value & Remarks \\
\hline Between Groups & 86.92 & 2 & 43.46 & $7.38^{*}$ & 0.001 & *Sig \\
\hline Between Groups & 3516.33 & 597 & 5.89 & & & \\
\hline Total & 3603.25 & 599 & & & & \\
\hline
\end{tabular}

Source: Research Fieldwork.

${ }^{*} p .001$, level significant $0.05, \mathrm{df}=2$ and 597 , critical $\mathrm{f}=7.38$.

\section{Discussion}

\section{Cultural belief and polio eradication}

The findings showed that the extent of polio eradication in the study area was determined by the extent of an individual's cultural belief. Thus, the stronger the cultural belief, the weaker the effort at polio eradication and vice versa. These findings corroborated with the findings of Ekong, [9], who maintained that cultural belief is an important factor that could improve or hinder the eradication of polio in Nigeria. This implies that, if one's extent of cultural belief is strong; it will have a negative effect on the effort in eradicating polio.

The findings were also in support of the findings of Ademuwagun, [11] and Renne, [12]. In their study, they observed that strong belief in culture and traditions of the people accounted for over 60 percent low utilization of infant immunization. On this basis, Renne, [12] submitted that there was high need for proper education of the people if they fight against these dreaded diseases of our time must end. This implies that, polio eradication was successful only when the populace cultural belief was worked on to reflect what was ideal in our modern society.

\section{Religious differences and polio eradication}

The findings revealed the differences in religious view and how it affected polio eradication in the study area. The findings showed that the effort by the Christian group was significant in polio eradication at 33.34, followed by others at 32.86 and Muslims at 26.93 respectively. This study corroborates with the findings of Warriach, [10], who observed that opposition by Muslim fundamentalists was a major factor in the failure of polio immunization programme. The study also agreed with Leblance, [15], who observed that all but two states in USA allowed parents to opt out of their children's otherwise, mandatory vaccination for religious reasons.

\section{Conclusion}

From the findings above, it is pertinent to conclude that, the seeming poor attitude and delay towards polio eradication as reflected in the underutilization of polio vaccine was due to the strong influence of the cultural belief of the people. This had resulted in the lukewarm and carefree attitude towards the use of polio vaccines as well as other modern health care services observed among the people in our society. Beside cultural belief, it could also be concluded that some religious beliefs seemed to negatively influence the use of drugs in the treatment of polio and related disorders. There is therefore a strong need to better inform the population of the benefits of vaccination in order to overcome the barriers of religious beliefs.

\section{References}

1. World Health Organization. Global Polio Eradication Initiative 20102012 strategic plan for interrupting polio worldwide. 2010. http://appablog.worldpress.com

2. Charles PD. Medical definition of health. 2021. https://www.medicinenet.com

3. Etobe El. Sociology of Health and Rehabilitation. Calabar: Chris-fon Noble Publisher. 2005.

4. Wikipedia. Poliomyelitis. 2010. http.en.wikipedia.org

5. Jegede AS. What led to the Nigerian boycott of the Polio vaccination campaign. Plos Med. 2007; 4: e73.

PubMed: https://pubmed.ncbi.nlm.nih.gov/17388657/

6. Pallandach MA. Ending use of oral poliovirus vaccine: A difficult move in the polio end game. N Eng J Med. 2017; 379: 801-803. PubMed:https://pubmed.ncbi.nlm.nih.gov/30157390/

7. Aylward RB, Linking J. Polio Eradication: Mobilizing and Managing the Human Resources. Bull World Health Organ. 2021; 83: 268-731. PubMed: https://pubmed.ncbi.nlm.nih.gov/15868017/

8. Hogan MO. Dictionary of Sociology. New Delli: Academic Publisher 2006.

9. Ekong EE. Rural sociology: An introduction and analysis of rural Nigeria. Uyo: Dove Educational Publisher. 2003.

10. Warriach HJ. Religious opposition to polio vaccination. Emerg Infect Dis. 2009; 15: 978. http://ede.gov/eid/content

11. Ademuwagun ZA. Problem and prospect of legitimizing and integrating of traditional healthcare system and method of modern therapy: the Igo-ora experience. Afr J Therapeu Sys. 1979: 15: 5-12.

12. Renne EP. Islam and immunization in northern Nigeria. Michigan: Centre for Afro-American and African Studies. 2007.

13. Bolu O, Nnadi C, Damisa E, Brara F, Siddigue A, et al. A progress towards poliomyelitis eradication - Nigeria: Morbidity and mortuary weekly report. 2018; 67: 253-256.

14. Integrated Regional Information Network. Hundreds death in measles outbreak. 2007. http://www.irinnews.org

15. Leblace S. Parents used religion to avoid vaccines. USA Today. 2007; https://www.usatoday.com/news/ 